\title{
Proposal of the instrument work-related musculoskeletal disorders index
}

\author{
Proposta do instrumento índice de distúrbios osteomusculares relacionados ao trabalho
}

\author{
Paulo Wenderson Teixeira Moraes ${ }^{1}$, Antonio Virgílio Bittencourt Bastos ${ }^{2}$
}

DOI 10.5935/2595-0118.20190047

\section{ABSTRACT}

BACKGROUND AND OBJECTIVES: The measurement of pain and discomfort from work-related musculoskeletal disorders is a conceptual and empirical challenge, considering the cognitive and subjective processes involved in the evaluation of somatic symptoms. The objective of this study was to construct a work-related musculoskeletal disorders index to evaluate musculoskeletal discomfort in workers with and without repetitive strain injuries/work-related musculoskeletal disorders, a syndrome that affects thousands of workers every year.

METHODS: The sample was composed of 182 bank clerks from the State of Bahia, 91 of whom were diagnosed with the syndrome.

RESULTS: The work-related musculoskeletal disorders index had a frequency distribution similar to the normal curve, with averages of 7.1 and 4.1 for the groups with and without a diagnosis, respectively.

CONCLUSION: In addition to the adequate psychometric properties, the proposed index was able to differentiate, satisfactorily, workers with and without a diagnosis of repetitive strain injuries/work-related musculoskeletal disorders.

Keywords: Pain, Pain measurement, Repetitive strain injuries, Work-related musculoskeletal disorders.

\section{RESUMO}

JUSTIFICATIVA E OBJETIVOS: A mensuração da dor e do desconforto oriundos de distúrbios osteomusculares relacionados ao trabalho é um desafio conceitual e empírico, tendo em vista os processos cognitivos e subjetivos envolvidos na avaliaçáo de sintomas somáticos. O objetivo deste estudo foi construir um

\footnotetext{
Paulo Wenderson Teixeira Moraes - (Dhttps://orcid.org/0000-0001-8037-0906;

Antonio Virgílio Bittencourt Bastos - (Dhttps://orcid.org/0000-0002-1322-5749.

1. Universidade Estadual da Bahia, Salvador BA, Brasil.

2. Universidade Federal da Bahia, Salvador, BA, Brasil.

Submitted on October 31, 2018

Accepted for publication on July 29, 2019.

Conflict of interests: none - Sponsoring sources: Fundação de Amparo à Pesquisa da Bahia (FAPESB).

Correspondence to:

Universidade do Estado da Bahia

Rua Silveira Martins, 2555 - Cabula

41150-000 Salvador, BA, Brasil.

E-mail: pwmoraes@yahoo.com

(C) Sociedade Brasileira para o Estudo da Dor
}

índice de distúrbios osteomusculares relacionados ao trabalho para avaliar o desconforto osteomuscular entre trabalhadores com e sem lesôes por esforço repetitivo/distúrbios osteomusculares relacionados com o trabalho, uma síndrome que acomete milhares de trabalhadores todo o ano.

MÉTODOS: Participaram da amostra 182 bancários do Estado da Bahia, sendo que 91 deles tinham o diagnóstico da síndrome. RESULTADOS: $\mathrm{O}$ índice de distúrbios osteomusculares relacionados ao trabalho apresentou distribuição de frequência semelhante à da curva normal, com médias de 7,1 e 4,1 para os grupos com e sem diagnóstico, respectivamente.

CONCLUSÃO: Além das propriedades psicométricas adequadas, o índice proposto se mostrou capaz de diferenciar, satisfatoriamente, trabalhadores com e sem diagnóstico de lesóes por esforço repetitivo.

Descritores: Distúrbios osteomusculares associados ao trabalho, Dor, Lesóes por esforço repetitivo, Mensuração da dor.

\section{INTRODUCTION}

Repetitive strain injuries or work-related musculoskeletal disorders (RSI/WRMD) is a syndrome that has become the subject of worldwide debate, impacting the workers' psychological distress and generating billionaire losses to society, according to literature reviews in the area ${ }^{1-3}$. The term RSI, however, is not yet consolidated as a scientific concept and is not cited in the International Classification of Diseases (ICD-10), although it presents itself as a notion widely used in the daily lives of many workers and has a significant effect on the description of musculoskeletal symptoms ${ }^{4-8}$. Pain is included in the International Classification of Functioning, Disability and Health (ICF) ${ }^{9}$ under code b280-b289, and pain sensation is defined as an unpleasant feeling, indicating an actual or potential injury to a body structure and is generally classified as acute or chronic ${ }^{10-12}$. Chronic pain, typical of musculoskeletal disorders, is the focal element in a "complex network of suffering that involves depression, somatic concern, physical limitation, sleep disorders, and hopelessness"13. The US Institute of Medicine has reported that chronic pain affects 100 million adults in the United States, resulting in an estimated cost of USD 635 billion due to spending on medical interventions and the poor productivity of those affected. With this in mind, an agenda was created to prevent the disease and increase research efforts ${ }^{14}$.

In this context, what effectively communicates when a person complains of pain? According to Cioff ${ }^{15}$, from the point of view of social cognition, three dimensions stand out in the interpretation of organic stimuli. 1) Somatic stimuli are guided by the 
individual's implicit theories about his physical symptoms, particularly by alleged cause-and-effect relationships between these symptoms and events that could potentially explain them; 2) the implicit theory and processes in which it is formed are greatly affected by the social context of the person; 3) personal, biomechanical, social and organizational factors converge and interact. Given these propositions, what is actually measured in the application of pain assessment instruments? In addition to representing the discomfort in the face of uncomfortable body sensations, the scores, or "degree of pain," also reflect the implicit theories that individuals have which, in turn, reflect the socio-historical context in which alleged cause-and-effect relationship is constructed, "regarded as shared" by all. What can be said is that the human being, in general, does not have the ability to access the "pain itself," but only the "pain" phenomenon that is mediated by his cognitive assessment. The meaning of pain is the "epistemological Achilles' heel" of the various constructs that are used in research and clinical practice, which can generate inaccurate diagnostic processes and support not always effective therapeutic practices $^{16,17,19,21}$.

The different pain keywords were analyzed in the construction of the McGill Pain Questionnaire (MPQ) $)^{22,23}$ and provided a fundamental repertoire for the assessment of different types of diseases, including musculoskeletal disorders. With the same objective, Couto ${ }^{24}$ elaborated the Ergonomics Census to assess RSI/ WRMD by selecting the following keywords: tiredness, shocks, pain, crackling, numbness, weight, loss of strength, aching sensation and tingling. These keywords are found in the Norms and Technical Manual $s^{25}$ and Normative Instruction No. $98^{26}$, as a reference for the characterization of the diagnosis, which consists of the usual clinical investigation steps, aiming to verify the existence of one or more of the nosological entities, the etiological factors, and aggravation.

Despite this diversity of pain keywords, the most widely used instrument for assessing work-related musculoskeletal symptoms, the Standardized Nordic Questionnaire ${ }^{27}$, uses only "pain" and "discomfort." In addition to having the human figure to mark the place of discomfort, there is the following general instruction: "have you had any kind of problem (pain, discomfort) during the last 12 months"? Then, it is asked if the person has avoided doing routine tasks at work or home because of the pain. It is also asked if the person has experienced such problems in the last seven days. A second part of the questionnaire is the detailing of neck and shoulder pain. However, besides few keywords for pain, there is no assessment of the intensity dimension, and the analyzes are made by dichotomous variables, which indicate whether or not the person has a problem in a particular region. Given the "stages of RSI/WRMD" described in the Brazilian technical norms ${ }^{25,26}$, and the different instruments to assess chronic pain, it is necessary to build an instrument that reflects the fundamental characteristic of RSI/WRMD, which is a chronic pain, but also incorporating the information on the impact on work and daily activities; thus discriminating the different stages of the syndrome and representing the various symptoms complaints. Moreover, for research in this domain, it is very relevant to produce a numerical variable capable of summarizing the information set of each subject about the RSI/WRMD phenomenon, enabling psychometric analysis and empirical testing of explanatory models.

Thus, this article aimed to construct a "musculoskeletal disorder index" (IDORT) to discriminate the chronicity of RSI/ WRMD-related symptoms, presenting data for index validation.

\section{METHODS}

Five expert doctors were asked to assess IDORT (Annex 1) and five people affected by RSI/WRMD syndrome to ascertain clarity and objectivity before applying the instrument on a large scale. Their considerations have been taken into account and corrected in the final version. The instrument is an adaptation of the Ergonomics Census proposed by Couto ${ }^{24}$ and the Nordic Musculoskeletal Questionnaire (MSQ $)^{27}$, but which also generated an overall score similar to that proposed in the Neuropathic Pain Symptom Inventory ${ }^{17}$. The IDORT index serves to measure an individual's cognitive assessment of discomfort in various areas of his body.

In order to improve pain severity assessment levels, ICF $\mathrm{ICodel}^{9}$ was taken into account, which suggests that the consequences of a person's pain capacity limitations be assessed from the amplitude of the following interval: "no" problem or "insignificant", "mild", "moderate", "severe" problem and ultimately "totally problematic".

The first question of IDORT referred to the size of the location of discomfort in the body. Questions 2 and 6 are work-related and signal the influence of work on discomfort. The questions indicating the dimension of discomfort intensity are 4, 7, and 10 . The dimension of symptom duration is represented in question 3. Regarding the dimension of pain quality, question 5 represents the pain keywords that best express what the subject feels. Finally, questions 8 and 9 assess the impact of discomfort on other non-work activities and work productivity, respectively. These 10 questions are the items that were analyzed later. From an aggregate measure of the questions of this instrument, the Musculoskeletal Disorders Index, which varies from 0 to 10, was obtained. The calculation of the score is a weighting of the 10 items as follows:

IDORT $=\left[\left(\sum \mathrm{p} * 10 / 8\right)+\left(\mathrm{t}_{\mathrm{r} *}, \mathrm{t} * 10 / 30\right)+(\mathrm{d} * 0 / 6)+(\mathrm{i} * 10 / 6)+\right.$ $\left(\sum s_{*} 10 / 9\right)+\left(\mathrm{t}_{\mathrm{ra}}+\mathrm{q}_{\mathrm{tra}}\right) * \mathrm{t}_{*} 2 / 30+\left(10-\mathrm{r}_{\mathrm{ep}}-\mathrm{q}\right)+(\mathrm{a} * 10 / 6)+\left(\mathrm{i}_{\mathrm{m}} * 10 / 6\right)+$ $\left.\left(\mathrm{r}_{\mathrm{em}} * 10 / 6\right)\right] / 10$.

Table 1 shows the keywords of the components of the equation. Each of the ten items is represented in the equation in its parenthesis and ranges from zero to 10 . The total sum is 100 , which was divided by 10 to return to the original scale. The reason there are different multipliers per item is so that all items receive equivalent weights in the equation, even though they have been measured differently.

The sample was exploratory and not random, based on the availability of bank clerks, who were approached in 38 different branches of the state of Bahia, from various public and private banks. Of the 320 subjects who received the questionnaire, only 220 consented to participate in the study and returned it duly completed. Of this total, 182 bank clerks said they had some 
Table 1. Specification of the components of the musculoskeletal disorder equation

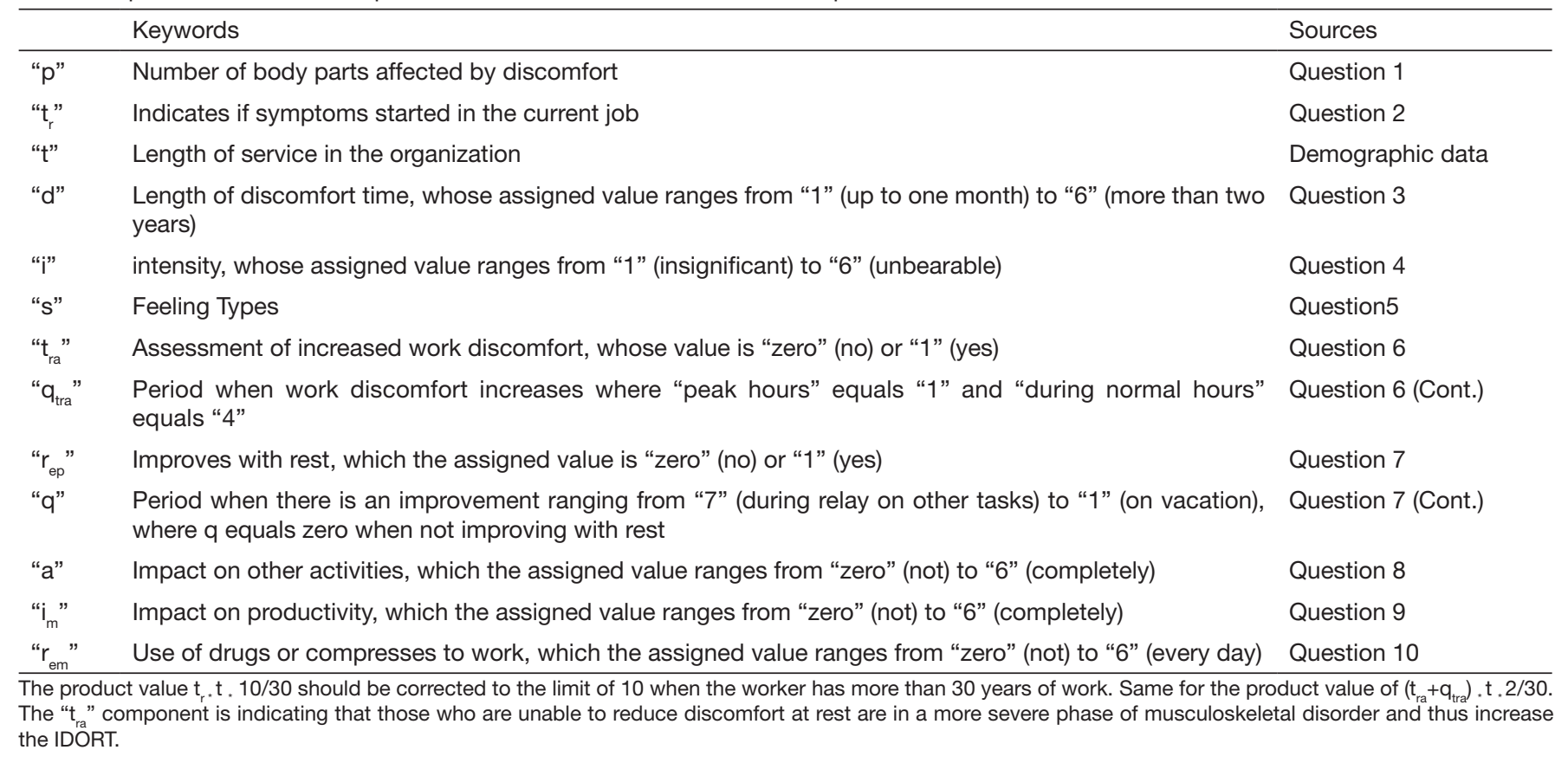

musculoskeletal disorder, and 91 also indicated that they were diagnosed with RSI/WRMD by a doctor.

All participants signed the Free Informed Consent Form (FICF). This article is the result of a research project submitted to the UEFS Ethics Committee, registered in this CEP under protocol 045/2011 (CAAE no 0043.059.000-11).

\section{Statistical analysis}

A post hoc analysis by the $\mathrm{G}^{*}$ Power program revealed that a sample of two groups of 91 individuals has a power (1-ß) of more than $95 \%$ to find a difference between means of a test applied to such groups if genuinely there is a difference in the population studied. Descriptive analyses of data frequency, variance (ANOVA), and factor analysis were performed. Also, to increase the reliability of the analysis of the factors of the scale, some basic prerequisites had to be checked ${ }^{31}$. With this in mind, when performing the principal component analysis (PCA) of the 10 items of the IDORT, the adequacy measure of the Kaiser-Meyer-Olkin sample was verified, which pointed out excellent adequacy $^{30}, \mathrm{KMO}=0.856$. Bartlett's sphericity test $\chi^{2}(45)=727.28$, $\mathrm{p}<0.001$, indicated that the correlations between the items were large enough for a PCA. Observing the eigenvalues for each component, three of them obtained eigenvalues above 1, which corresponds to the Kaiser criterion.

\section{RESULTS}

The average age of the 182 bank clerks was approximately 41 years old, with a standard deviation of 10 years, with $40 \%$ being men. For a more detailed description of demographic data, it was possible to consult more extensive previous works on this sample $e^{4,31}$. There are three important prerequisites for using parametric tests that contribute to the reliability of statistical analysis: the variable must have a distribution similar to a normal distribution, the variance must be the same throughout the distribution (homogeneity of variance), and the measurement should be independent among participants ${ }^{30}$. In the case of IDORT, kurtosis and asymmetry were not significantly different from zero, indicating a close to normal distribution. The completion of the questionnaire was individual, and, probably, there was independence of the answers of each participant. Therefore, the IDORT was able to satisfactorily describe the symptoms of RSI/WRMD and effectively discriminate the group diagnosed with RSI/WRMD in relation to those with only musculoskeletal disorders.

By visually analyzing figure 1 , a histogram of the frequency distribution of IDORT, a behavior similar to a normally distributed variable with little kurtosis and little asymmetry was observed.

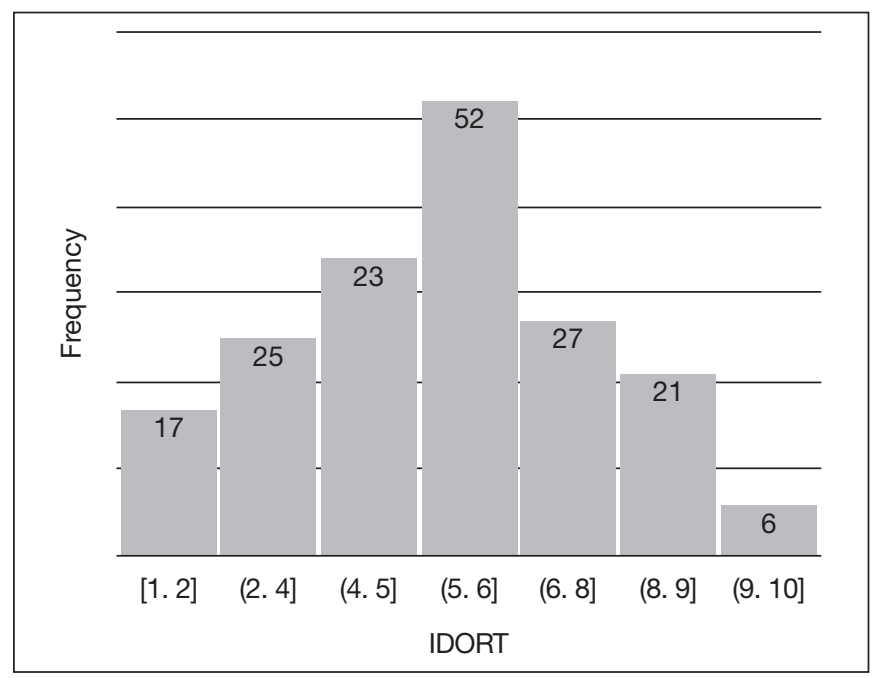

Figure 1. Histogram of the frequency distribution of the musculoskeletal disorders index 
igure 2 shows the means of IDORT by group. Those diagnosed with RSI/WRMD had a much higher mean than those who only had musculoskeletal discomfort (MD), respectively, 7.13 $(\mathrm{SD}=1.21)$ and $4.12(\mathrm{SD}=1.17)$.

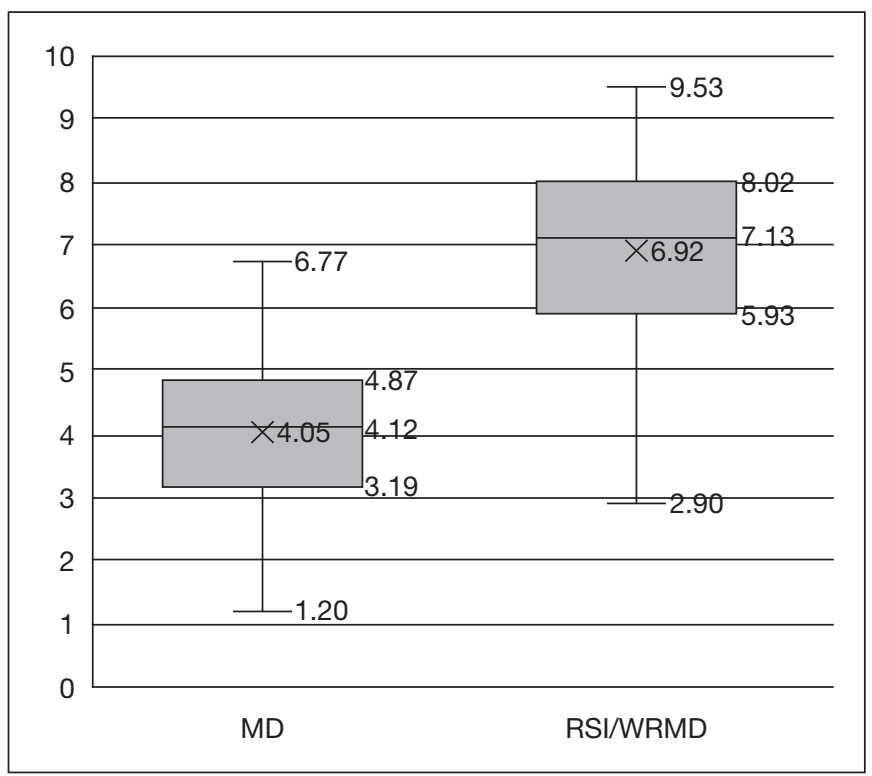

Figure 2. Distribution of the musculoskeletal disorders index around the respective means of the MD and RSI/WRMD groups

The difference between these means was significant $(\mathrm{p}<0.001$, $\mathrm{F}=278.28$ ) and by the Levene homogeneity test of variance ${ }^{30}$, it was found that the variances did not differ significantly for these two groups.

It was observed that two cases in the "MD" group are beyond the range of 3 standard deviations and can be considered as outliers. Case 121 stands out because it has high chronic pain, but is not diagnosed with RSI/WRMD, while case 119 may be acute and non-chronic pain.
Through table 2, it is possible to observe that IDORT is structured based on three factors: 1 - scope and intensity of pain; 2- relationship with work; and 3 - chronicity of pain. The correlation of each item with its respective factor is significant. The correlation of each item with the other factors proved to be insignificant, except for item Q3. Cronbach's alpha coefficient was 0.884 for the first factor and 0.701 for the second. Only the third factor obtained an unsatisfactory result of 0.325 . Item Q3 showed a significant correlation in both factor 3 and factor 1 , indicating that this item has some ambiguity or wider association with pain. Thus, "the time you feel the pain" is also slightly associated with the factor "scope and intensity of pain."

The variance explained by the first factor was $44.4 \%$, the second factor was $13.2 \%$ and the third $10.9 \%$. The three factors combined explained $68.5 \%$ of the variance. By the Catell ${ }^{30}$ scree plot criterion, the inflection points also had three dimensions. To verify the alleged correlation between these three factors, it was decided to perform the oblique rotation of the factors, using the Promax method, with kappa equal to four (4). Table 2 shows that the first factor consists of items related to impact (Q8 and Q9), intensity (Q4 and Q10), location, and type of pain (Q1 and Q5).

Therefore, the impact on daily activities, the number of sites and types of pain merged with the intensity forming the dimension "scope and intensity of pain". The second dimension was named "relationship with work" and brought together the items "started with current work" (Q2) and "how do you feel increases with work" (Q6). These two items were multiplied by the length of service in the company and, therefore, are closely correlated. This explains the high factorial loads. Finally, the third dimension was "chronicity of pain," since the two items aggregated in this factor are aspects that describe chronic pain, namely, "time" (Q3) and "does not improve with rest" (Q7). The oblique rotation of the factors proved to be a more appropriate solution, considering that through it was verified and evidenced the significant correlation between the factors.

Table 2. Summary of results of the exploratory factor analysis of musculoskeletal disorders index $(n=182)$

\begin{tabular}{|c|c|c|c|c|c|}
\hline & & & \multicolumn{3}{|c|}{ Components } \\
\hline & & & 1 & 2 & 3 \\
\hline \multirow[t]{6}{*}{ Scope and intensity of pain } & Q8 & Affects other activities outside of work & .869 & -.207 & .054 \\
\hline & Q9 & Affects productivity & .868 & -.053 & -.126 \\
\hline & Q10 & Has been taking drugs to work & .803 & .015 & .057 \\
\hline & Q4 & Pain intensity & .766 & .002 & .198 \\
\hline & Q1 & No. of body parts & .758 & .072 & -.054 \\
\hline & Q5 & No. of sensations & .749 & .138 & -.211 \\
\hline \multirow[t]{2}{*}{ Relationship with work } & Q2 & Started at current job* & -.147 & .925 & .057 \\
\hline & Q6 & What you feel increases with work* & .121 & .819 & -.063 \\
\hline \multirow[t]{2}{*}{ Chronicity of pain } & Q7 & Improves with rest & -.092 & -.022 & .943 \\
\hline & Q3 & Time when you feel discomfort & .393 & .163 & .403 \\
\hline Eigenvalues & & & 4.436 & 1.319 & 1.100 \\
\hline$\%$ f variance explained & & & 44.4 & 13.2 & 10.9 \\
\hline Cronbach's Alpha & & & 0.884 & 0.701 & 0.325 \\
\hline
\end{tabular}

\footnotetext{
${ }^{*}$ multiplied by the length of service
} 
IDORT's overall Cronbach's alpha ( $\alpha$ ) was 0.843 . The value of $\alpha$ for the first factor was 0.884 , for the second 0.701 and the third 0.325 . The item "improvement with rest" (Q7) when removed increases $\alpha$ reliability from 0.843 to 0.861 and its correlation with IDORT was the only correlation of an item with a total score below 0.4 . Despite this unfavorable result only for this aspect, the item was maintained because it represents a relevant data of the diagnosis of chronic symptoms and, even with its presence, the global $\alpha$ remained at a very satisfactory level.

\section{DISCUSSION}

The proposed factors "Scope and intensity of pain", "Relationship with work", and "Chronicity of pain" only validated a possibility of describing symptoms related to RSI/WRMD syndrome. Communication of such symptoms is a complex process involving cognitive assessment and cultural context. Objectifying this information is a strategic step in analyzing the relationships of these symptoms to psychosocial factors in large samples. The full meaning of pain communication, however, requires a multidisciplinary effort. The words that are used to characterize feelings and sensations are only the superficial dimension of a more profound phenomenon. From the psychic point of view, there may be pain-latent contents that are revealed only through careful analysis of the subject's unconscious ${ }^{32}$.

In a previous study ${ }^{29}$, the IDORT showed significant correlations with psychosocial factors such as psychological stress, assessment of reward received, work autonomy and career commitment, demonstrating the feasibility of using the index as an outcome marker in epidemiological studies. This also indicates that IDORT is related to broader phenomena in the world of work that are often revealed by pain.

Regarding psychosocial factors, some suggestions may be useful for future studies. The first relates to the research design that should incorporate the longitudinal aspect, enabling the foundation of causal relationships in the development of symptoms. In addition, longitudinal studies may generate greater consistency in the use of indices for the assessment of treatments and intervention in RSI/WRMD. Also, in professional practice, in the area of occupational health, IDORT can be an indicator to assess the effectiveness of treatments, and it is possible to follow, briefly, the evolution of musculoskeletal symptoms.

Another way to validate an index is to invest in building an item bank and calibrating it through the Item Response Theory. This methodology can positively impact the ability to predict RSI/ WRMD cases, as well as assist in understanding the impact of psychosocial factors through the analysis of more complex models, possible in this type of approach.

The analysis of psychometric properties corroborated the validity of the scale in assessing pain dimensions, comparable to other studies in the area ${ }^{11,17,18}$. The self-assessment, made possible by the questionnaire, successfully allowed the discrimination and quantification of the dimensions relevant to the assessment of chronic pain. Comparing with other instruments ${ }^{11}$, the IDORT obtained a satisfactory psychometric validation, confirming the factors that constitute the scale through the internal consistency of the correlations between the items, but the "intensity" factor was separated from the "dysfunction" factor, in some studies 18,20 , while it was combined in another ${ }^{21}$, similar to this work. The time in which pain arose was associated with pain intensity, differing from other research that did not find such association ${ }^{21}$. The IDORT instrument, which represents, among other things, musculoskeletal symptoms and signs that indicate one piece of the worker's health and well-being, was successful in discriminating bank clerks who reported being diagnosed with RSI/WRMD by some doctor, generating a new possibility to assess the characteristic discomfort of this syndrome. Given the conceptual fragility that implies difficulties in diagnosis, the possibility of creating a criterion arising from the chronicity of symptoms can be a useful tool to support the diagnosis.

This research did not rely on the diagnosis of medical experts to confirm the self-report of workers, making the results vulnerable to criticism. However, even not controlling the reliability of the self-report, the results of this work point to the discriminative power that the term RSI/WRMD produced in the studied sample. Although not yet a concept in itself, but only a "notion" that has been strengthened by widespread use by health professionals and society, the term RSI/WRMD characterizes a specific group of people who have more severe musculoskeletal symptoms and have been discriminated by IDORT.

\section{CONCLUSION}

This study described the development of a new instrument to measure pain in its different dimensions: intensity, relationship with work, and dysfunction. The resulting score synthesized the information of the self-report of the symptoms and proved to be a promising alternative for organizing the dimensions of the phenomenon that are usually assessed separately. In addition to the practicality of the resulting score, IDORT assists in researching the association of RSI/WRMD symptoms with psychosocial work factors. 
Annex 1. Work-related Musculoskeletal Disorders Self-Assessment Instrument

Available at https://pospsi.ufba.br/sites/pospsi.ufba.br/files/paulo_wenderson_tese.pdf

This work-related musculoskeletal disorders self-assessment tool consists of objective questions that demand your attention to body perception and the assessment of the impact of work-related musculoskeletal disorders. ALL questions must be answered carefully, avoiding to leave them blank, not to compromise the analysis of the results. It consists of 3 parts:

I. Characterization data;

II RSI/WRMD data;

III Self-assessment of body discomfort symptoms.

We are grateful for your participation and contribution to the advancement of scientific knowledge in the area of occupational health of the worker

I. Characterization data:

\begin{tabular}{|c|c|c|c|c|c|c|c|c|c|}
\hline 1. Gender & \multicolumn{2}{|l|}{$\square$ Male } & \multicolumn{2}{|c|}{$\square$ Female } & \multicolumn{3}{|c|}{ 3. Marital status } & \multicolumn{2}{|l|}{ 5. $\mathrm{N}^{\circ}$ of children } \\
\hline 2. Idade & \multicolumn{2}{|l|}{ anos } & & & \multicolumn{3}{|c|}{ 4. $N^{\circ}$ de dependentes } & \multicolumn{2}{|c|}{ 6. Idade do filho caçula: } \\
\hline \multicolumn{5}{|c|}{ 7. What is your level of education? (Specify the course) } & \multicolumn{5}{|c|}{ 7.1 Are you studying? $\square$ Yes } \\
\hline \multicolumn{2}{|c|}{$\square$ High school completed } & \multicolumn{3}{|c|}{$\square$ Incomplete higher education } & & & & & \\
\hline \multicolumn{2}{|c|}{$\square$ Maters' degree } & \multicolumn{3}{|c|}{ Complete higher education } & & & & & \\
\hline \multicolumn{2}{|l|}{$\square \mathrm{PhD}$} & \multicolumn{3}{|c|}{ Post-Graduation } & & & & & \\
\hline \multicolumn{4}{|c|}{ 8. How old were you when you start working? } & years & & \multicolumn{3}{|c|}{ 8.1 Length of service in the organization } & years \\
\hline \multicolumn{3}{|c|}{ 9. What's your religion? } & \multicolumn{2}{|c|}{ 口 I have no religion } & & & \multicolumn{2}{|c|}{ Are you practising? $\square$ Yes } & \\
\hline$\square$ Catholic & a Prote & tant & $\square$ Spil & & $\square$ UDV & & uddhist & $\square$ Candomblé & $\square$ Other: \\
\hline
\end{tabular}

II. Data about RSI/WRMD (IF ANSWERING "NO" TO QUESTION 1, GO TO PART III)

\begin{tabular}{|l|l|l|l|}
\hline 1. Have you ever been diagnosed with RSI/WRMD? & $\square$ No & $\square$ Yes & When? \\
\hline a. Which doctor made the diagnosis? & $\square$ From the public health service & $\square$ From the bank & $\square$ Private \\
\hline & $\square$ From the Union & $\square$ Other: & \\
\hline b. Do you have a specific diagnosis? & $\square$ Tendonitis & $\square$ Tenosynovitis & $\square$ Epicondylitis \\
\hline & $\square$ Carpal tunnel syndrome & $\square$ Bursitis & $\square$ Other: \\
\hline 2. Are you currently: & $\square$ Recovered & $\square$ Under treatment & $\square$ In professional rehabilitation \\
\hline 3. Have you ever missed work because of RSI/WRMD? & $\square$ No & $\square$ Yes & For how long? \\
\hline 4. Have you been on sick leave due to RSI/WRMD? & $\square$ No & $\square$ Yes & For how long? \\
\hline 5. Are you currently on sick leave? & $\square$ No & $\square$ Yes & For how long? \\
\hline
\end{tabular}

III. Self-assessment of body discomfort symptoms

1. Have you experienced any discomfort in your upper limbs or spine in the past 40 days? Mark the site(s) with an "X" in the figure below.

(A) No discomfort. Then, you do not need to answer questions 2 through 9 below.

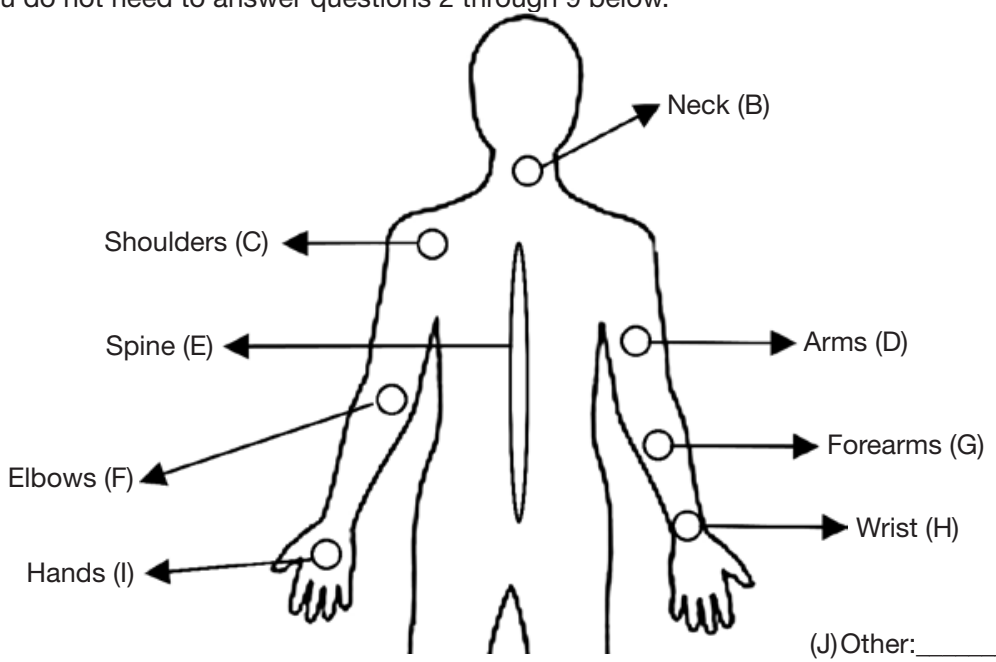




\begin{tabular}{|c|c|c|c|c|c|c|}
\hline \multicolumn{5}{|c|}{ 2. When did the discomfort begin, were you at the current job? } & $\square$ No & a Yes \\
\hline \multicolumn{7}{|c|}{ 3. How long have you been feeling this discomfort? } \\
\hline$\square$ Up to 1 month & $\square 1$ to 3 months & $\square 3$ to 6 months & $\square 6$ to 12 months & $\square 1$ to 2 years & $\square$ more than 2 years & \\
\hline \multicolumn{7}{|c|}{ 4. What you feel, you rate as: } \\
\hline 口1. Insignificant & 2. Mild & 3. Moderate & 4. Strong & 5. Very strong & 6. Unbearable & \\
\hline \multicolumn{7}{|c|}{ 5. Write down the most critical site(s) of discomfort ( $1^{\text {st }}$ to $\left.3^{\text {rd }}\right)$ and tick the types of sensation below. } \\
\hline Body site: & \multicolumn{2}{|l|}{$1^{\circ}:$} & \multicolumn{2}{|l|}{$2^{\circ}:$} & \multicolumn{2}{|l|}{$3^{\circ}:$} \\
\hline \multirow{9}{*}{$\begin{array}{l}\text { Types of } \\
\text { sensation: }\end{array}$} & \multicolumn{2}{|l|}{$\square$ Fatigue } & \multicolumn{2}{|l|}{$\square$ Fatigue } & \multicolumn{2}{|l|}{$\square$ Fatigue } \\
\hline & \multicolumn{2}{|l|}{$\square$ Shocks } & \multicolumn{2}{|l|}{$\square$ Shocks } & \multicolumn{2}{|l|}{ a Shocks } \\
\hline & \multicolumn{2}{|l|}{ Pain } & \multicolumn{2}{|l|}{$\square$ Pain } & \multicolumn{2}{|l|}{ D Pain } \\
\hline & \multicolumn{2}{|l|}{ Crackling } & \multicolumn{2}{|l|}{ C Crackling } & \multicolumn{2}{|l|}{ C Crackling } \\
\hline & \multicolumn{2}{|l|}{ Numb } & \multicolumn{2}{|l|}{$\square$ Numb } & \multicolumn{2}{|l|}{$\square$ Numb } \\
\hline & \multicolumn{2}{|l|}{$\square$ Weight } & \multicolumn{2}{|l|}{$\square$ Weight } & \multicolumn{2}{|l|}{$\square$ Weight } \\
\hline & \multicolumn{2}{|c|}{$\square$ Loss of strength } & \multicolumn{2}{|l|}{$\square$ Loss of strength } & \multicolumn{2}{|l|}{$\square$ Loss of strength } \\
\hline & $\square$ Feeling sore & & $\square$ Feeling sore & & $\square$ Feeling sore & \\
\hline & 口 Tingling & & $\square$ Tingling & & a Tingling & \\
\hline 6. Does what you & eel increase when & are working? & & $\square$ No & Yes When? (Answe & below) \\
\hline During the norm & al working hours & $\square$ During overtime & $\square$ At nig & ht work & $\square$ At peak times & \\
\hline 7. What do you fe & improves with res & & & $\square$ No & $\square$ Yes When? (Answe & below) \\
\hline$\square$ When taking tur & is with other tasks & & Durin & break time & $\square$ At lunch break & \\
\hline When worktime & is over & $\square$ At night & $\square$ On w & ekends & $\square$ On vacation & \\
\hline 8. Has the discom & ort affected other & tivities outside of wc & & & & \\
\hline$\square$ No & $\square$ Very little & $\square$ A little & $\square$ Somehow & $\square$ A lot & $\square$ Very much & $\square$ Completely \\
\hline 9. Has the discom & ort affected your $w$ & k productivity? & & & & \\
\hline$\square$ No & $\square$ Very little & $\square$ A little & Somehow & $\square$ A lot & $\square$ Very much & $\square$ Completely \\
\hline 10. Are you taking & drugs or using pat & es or bandage to $\mathrm{w}$ & & & & \\
\hline$\square$ No & $\square$ Very little & $\square$ A little & D Sometimes & $\square \mathrm{A}$ lot & Almost always & Everyday \\
\hline 11. Have you had & ny medical treatm & & $\square$ No & $\square$ Yes & Which: & \\
\hline 12. Do you practic & physical activity? & & & & & \\
\hline$\square$ No & $\square$ Very little & $\square$ A little & $\square$ Somehow & $\square$ A lot & $\square$ Almost always & Everyday \\
\hline
\end{tabular}

\section{REFERENCES}

1. Bongers PM, Ijmker S, van den Heuvel S, Blatter BM. Epidemiology of work-related neck and upper limb problems: psychosocial and personal risk factors (part I) and effective interventions from a bio behavioural perspective (part II). J Occup Rehabil. 2006;16(3):272-302

2. Coovert MD, Thompson LF. Technology and workplace health. In: Quick JC, Tetrick LE, editors. Handbook of occupational health psychology. Washington: American Psychological Association; 2003. 221-41p.

3. Moraes PW, Bastos AV. As LER/DORT e os fatores psicossociais. Arq Bras Psicol. 2013;65(1):2-20

4. Moraes PW, Bastos AV. Os Sintomas de LER/DORT: um estudo comparativo entre bancários com e sem diagnóstico. Psicologia: Ciência e Profissão. 2017;37(3):1-14.

5. Cheng J. Overview of Pain States. In: Cheng J, Rosenquist RW, editors. Fundamentals of Pain Medicine. Cham: Springer; 2018.

6. Sousa FF, Silva JA. A métrica da dor (dormetria): problemas teóricos e metodológicos. Rev Dor. 2005;6(1):469-513.

7. Sousa FF, Pereira LV, Cardoso R, Hortense P. Escala Multidimensional de Avaliação de Dor (EMADOR). Rev Latino-Am Emfermagem. 2010;18(1):1-9.

8. Sardá Júnior JJ, Nicholas MK, Pimenta CA, Asghari A, Thieme AL. Validação do questionário de incapacidade Roland Morris para dor em geral. Rev Dor. 2010;11(1):28-36.

9. WHO. International Classification of Functioning, Disability and Health - IFC. Geneva: World Health Organization; 2001.

10. Russo CM, Brose WG. Chronic pain. Ann Rev Med. 1998;49(1):123-33.
11. Smith BH, Penny KI, Purves AM, Munro C, Wilson B, Grimshaw J, et al. The Chronic Pain Grade questionnaire: validation and reliability in postal research. Pain. 1997;71(2):141-7.

12. Von Korff M, Dworkin SF, Le Resche L. Graded chronic pain status: an epidemiologic evaluation. Pain. 1990;40(3):279-91.

13. Chapman CR, Syrjala KL. Measurement of Pain. In: Loeser JD, editor. Bonica's Management of Pain. Lippincott Williams \& Wilkins Publishers: Philadelphia; 2001. 309-28p.

14. Gatchel RJ, Reuben DB, Dagenais S, Turk DC, Chou R, Hershey AD, et al. Research agenda for the prevention of pain and its impact: report of the work group on the prevention of acute and chronic pain of the Federal Pain Research Strategy. J Pain. 2018;19(8):837-51.

15. Cioff D. Somatic interpretation in cumulative trauma disorders: a social cognitive analysis. Beyond biomechanics: psychosocial aspects of musculoskeletal disorders in office work. CRC Press: London; 1996. 313p.

16. Amtmann D, Cook KF, Jensen MP, Chen WH, Choi S, Revicki D, et al. Development of a PROMIS item bank to measure pain interference. Pain. 2010;150(1):173-82.

17. Bouhassira D, Attal N, Fermanian J, Alchaar H, Gautron M, Masquelier E, et al Development and validation of the Neuropathic Pain Symptom Inventory. Pain. 2004;108(3):248-57.

18. Bracher ES, Pietrobon R, Eluf-Neto J. Cross-cultural adaptation and validation of a Brazilian Portuguese version of the chronic pain grade. Qual Life Res. 2010;19(6):847-52.

19. Dixon D, Pollard B, Johnston M. What does the chronic pain grade questionnaire measure? Pain. 2007;130(3):249-53.

20. Toledo FO, Barros PS, Herdman M, Vilagut G, Reis GC, Alonso J, et al. Cross-Cul- 
tural adaptation and validation of the Brazilian Version of the Wisconsin Brief Pain Questionnaire. J Pain Symptom Manage. 2013;46(1):121-30.

21. Von Korff M, Ormel J, Keefe FJ, Dworkin SF. Grading the severity of chronic pain. Pain. 1992;50(2):133-49.

22. Melzack R. The McGill Pain Questionnaire: major properties and scoring methods. Pain. 1975;1(3):277-99.

23. Melzack R. The short-form McGill pain questionnaire. Pain. 1987;30(2):191-7.

24. Couto HA. Gerenciando a LER e os DORT nos tempos atuais. Belo Horizonte-MG: Ergo Editora; 2007

25. Brasil. Diagnóstico, tratamento, reabilitaçáo, prevençáo e fisiopatologia das LER/ DORT. Brasília: Ministério da Saúde; 2001.

26. Brasil. Instruçấo Normativa no 98 INSS/DC, de 05 de dezembro de 2003. DOU DE 10/12/2003. 2003.
27. Kuorinka I, Jonsson B, Kilbom A, Vinterberg H, Biering-Sorensen F, Andersson G, et al. Standardised Nordic questionnaires for the analysis of musculoskeletal symptoms. Appl Ergon. 1987;18(3):233-7.

28. Zare Harofteh Z, Bahrevar V, Madani SM. Are the musculoskeletal pains the most important health problem for employees of mellat bank? A cross sectional study in Yazd, Iran. Int J Musculoskeletal Pain Prev. 2017;2(4):333-7.

29. Moraes PWT. O efeito dos fatores psicossociais e dos vínculos com a carreira nos sintomas de LER/DORT entre bancários da Bahia. Salvador: Universidade Federal da Bahia; 2014.

30. Field AP. Discovering statistics using SPSS. London: Sage; 2009.

31. Thompson B. Exploratory and Confirmatory Factor Analysis: Understanding Concepts and Applications. Washington: American Psychological Association; 2004.

32. Lucire Y. Constructing RSI: belief and desire. Sydney: UNSW Press; 2003. 